\title{
Utilization of Biogas Reactor Waste (Bio-slurry) to Control of Club Root Disease on Cabbage Plants (Brassica oleracea L.)
}

\author{
I. Made Sudana*, Gusti Ngurah Raka and D.P. Arta Jaya
}

Faculty of Agriculture, Udayana University, Indonesia

*Corresponding author

\begin{tabular}{|c|}
\hline Keywords \\
\hline $\begin{array}{l}\text { Cabbage plants, } \\
\text { Biogas reactors, } \\
\text { Bioslurry, } \\
\text { Plasmodiophora } \\
\text { brassicae, } \\
\text { Antagonist } \\
\text { microbes }\end{array}$ \\
\hline Article Info \\
\hline $\begin{array}{l}\text { Accepted: } \\
\text { 04 August } 2019 \\
\text { Available Online: } \\
\text { 10 September } 2019\end{array}$ \\
\hline
\end{tabular}

\section{Introduction}

Clubroot disease is one of the most important diseases in cabbage plants (Brassica spp.) (Karling, 1968; Voorrips, 1995). This disease is also called swollen root disease (Djatnika, 1989) caused by the Plasmodiophora brassicae Wor. In Indonesia, this disease causing loss of cabbage crops around $88.60 \%$
Cabbage is a plant that has important economic value for farmers, and a source of nutrition for the community. But lately cabbage plants often find it difficult to cultivate, due to the presence of clubroot. This clubroot is caused by the pathogen Plasmodiophora brassicae. Various ways of controlling have been carried out to control this disease both physically and chemically have not provided good results. Utilization of biogas reactor waste (bioslurry), needs to be further investigated in addition to fertilizing plants, it can also be used as a biological control agent for pathogenic plants. Biogas reactor waste (bioslurry), both liquid and solid, is rich in microorganisms, perhaps some of which are antagonistic microbes or natural enemies of clubroot root pathogens. From the results of the study it turned out that Bioslurry was able to increase plant growth, and reduce the clubroot infection. Organic fertilizer from biogas reactor waste is good enough to increase the growth of cabbage compared to organic fertilizer used by farmers. Bioslurry from cow manure is very good to increase the growth of cabbage plants, both plant height, number of leaves and amount of leaf chlorophyll when compared with bioslurry from chicken, pork and goat manure. Bioslurry from goat manure has the lowest ability to increase the growth of cabbage. In order to protect cabbage from clubroot infection, the results of the study showed that organic fertilizer from biogas reactor waste, namely Bioslurry from Cattle could suppress clubroot infection up to $20.83 \%$, while control of clubroot root infection rates reached $85 \%$, while bioslurry from Goats only can reduce root disease only $65 \%$, so it is not good to use as a control device for clubroot. 
cultivating the plant of the Brassicaceae family on the land, because this pathogen has a high resistance to environmental changes in the soil. This is because these pathogens can live in the soil by utilizing organic matter in the soil so that the cabbage is no longer suitable to be cultivated on the land (Agrios, 2005).

In Bali various ways of controlling clubroot disease have been done, but have not been successful. According to farmers in Kembangmerta village, Baturiti Subdistrict, Tabanan Regency, various ways of control have been carried out by farmers. Some of these efforts are by giving dolomite lime, the application of several types of synthetic fungicides, and the use of several varieties of cabbage seeds imported from Japan such as YCR-Anju and YCR-Tae which are resistant to clubroot root (Arya et al., 2000 in Hendriani et al., 2012), but the results have not shown satisfactory.

Utilization of biogas reactor waste (bioslurry), needs to be further investigated in addition to fertilizing plants can also be used as biological control agents for plant pathogens (Klinton et al., 2017). Biogas reactor waste (bioslurry), both liquid and solid forms, rich in microorganisms, maybe some of them are antagonistic microbes or natural enemies of clubroot root pathogens.

\section{Bio-slurry}

Bio-slurry or biogas waste is a product of biogas processing made from livestock manure and water through an anaerobic fermentation process in a closed tank. Waste coming out of outlet holes, called bio-slurry in liquid form tends to be solid, light brown or green and tends to darken, little or no gas bubbles, odorless and does not invite insects. When it has solidified and dried, the bio-slurry color turns to dark brown. Drying Bio-slurry is sticky, tough and not shiny, and has the ability to bind good water. According to Risnawaty (2015), bioslurry contains many microbes and some of them can be natural enemies of plant pathogens

\section{Materials and Methods}

\section{Preparation of organic bio-slurry fertilizer}

Bio-slurry fertilizers used are bio-slurry from cow manure, pig manure, chicken manure and goat manure. Cow manure bio-slurry is taken directly from Simantri in Bali which runs Biogas Reactors to produce fuel gas from cow manure, while bio-slurry, pig, chicken or goat manure is taken directly on pig, chicken or goat farms that run biogas reactors.

\section{Treatment}

A. Chicken manure Bioslurry organic fertilizer

B. Pig manure Bioslurry organic fertilizer

C. Goat manure Bioslurry organic Fertilizer

D. Cow manure Bioslurry organic Fertilizer

E. Plants not given Bioslurry organic fertilizer

F. Control, plants are treated with fertilizer according to the habits of farmers

\section{Planting and observation}

Before planting, the soil is processed until it is ready to be planted and treatment plots 1 x 2 $\mathrm{m}$ in size, seedlings that have been sown in nursery beds and aged 21 days are moved to experimental plots.

Experimental plots that have been given basic fertilizer, namely solid Bioslurry fertilizer in accordance with the treatment dose of 20 tons / $\mathrm{Ha}$, then every month additional fertilizer is given, namely liquid Bioslurry which is the type according to treatment, by pouring near the roots of each plant in the experimental plot with a dose of $250 \mathrm{ml}$ per tree, but before application the Bioslurry must be diluted by 
adding water $1: 1$, the distance of the plant per plot is $20 \times 20 \mathrm{~cm}$

This study uses a completely randomized design using 4 replications with 6 treatments and the plants are well maintained until the harvest is observed;

1. Plant height

2. Number of leaves, cabbage plants,

3. Chlorophyll content in cabbage leaves

4. Percentage of clubroot disease by calculating plant symptom of clubroot which is the growth of dwarf or withered plants

$$
\mathrm{P}=\frac{\mathrm{n}}{\mathrm{N}} \mathrm{X} 100
$$

$\mathrm{P}=$ percentage of clubroot disease

$\mathrm{n}=$ number of infected plants

$\mathrm{N}=$ total number of plants

5. When harvesting, the symptoms of clubroot on the the plant roots are also weighed

6. Weight of cabbage plants

7. Crop harvest weight produced

\section{Results and Discussion}

Effect of bio slurry on vegetative growth of cabbage plants

After cabbage plants are given Biogas waste, namely bioslurry from chicken manure (A), Pig manure (B), Goat manure (C) and Cow manure (D), do not use bioslurry (E) and Fertilization which is usually not used by farmers on cabbage, $(F)$, then the vegetative growth produced on cabbage can be seen in Table 1

In table 1, it appears that the higher the plant, the more number of leaves produced as well as the amount of chlorophyll produced more this can be shown in the treatment of use of Cow bioslurry, which results in plant height, number of leaves and the highest amount of chlorophyll and different treatment others. Then followed by bioslurry chicken manure, pig and goat. With the large number of leaves, more and more carbohydrate is produced so that more energy is produced for the purposes of metabolism in plant cells to produce compounds that are beneficial for plant growth and production and increase plant resistance to pests and plant diseases.

Here it is clear that the use of Bioslurry fertilizer can significantly increase the growth of cabbage compared to plants without bioslurry use, treatment $\mathrm{E}$ and $\mathrm{F}$. However, among bioslurry, it turns out that bioslurry from goat manure is not good for fertilizer as cabbage.

The effect of bio slurry on generative growth and the rate infection of clubroot on cabbage plants pada

After the cabbage plants were treated with biogas waste, namely bioslurry as organic fertilizer, the generative growth and the rate of clubroot disease infection in cabbage can be seen in Table 2.

In Table 2, it appears that bioslurry cow manure can suppress clubroot infection compared to other treatments with an infection percentage of $20.83 \%$. This is because vegetative growth after cabbage is given bioslurry cow manure is quite good, because the amount of chlorophyll produced by the leaves is the most compared to other treatments, so carbohydrates are produced, which can be metabolized to energy for plant. Then this energy will be used for metabolism to produce compounds that can inhibit the growth of clubroot root pathogens. With the reduction of clubroot disease, the number of plants that produce more crops and the weight of each crop are heavier so that the highest crop production compared to other treatments. 
From the table above it can be seen that bioslurry of cow manure is best used to control clubroot root disease in cabbage plants and increase the production of cabbage plants. So to develop organic agriculture in cabbage can use bioslurry fertilizer cow manure and using biopesticides with active ingredients of plant extract has the potential to inhibit the growth of pathogens or biopesticides with active ingredients of microbial antagonists.

From Table 2 it also appears that fertilization using bioslurry from livestock manure is able to control clubroot disease and increase crop production compared to the treatment of plants without fertilizer with bioslurry. From the research results of Boteroa et al., (2019) Clubroot disease in Latin America can be controlled properly using microbial antagonists Trichoderma koningiopsis and Trichoderma harzianum even though in Latin America it has air humidity and extreme temperatures. Possibly the bioslurry of cattle manure used in this study contained a lot of tricoderma (Fig. 1-5).

Table.1 Effect of use of bio slurry on vegetative growth of cabbage plants

\begin{tabular}{|l|c|c|c|}
\hline \multirow{2}{*}{$\begin{array}{l}\text { Bioslurry Fertilizer } \\
\text { From livestock manure }\end{array}$} & \multicolumn{3}{|c|}{$\begin{array}{c}\text { Vegetative growth of cabbage plants after being given Bioslurry } \\
\text { Fertilizer }\end{array}$} \\
\cline { 2 - 4 } & $\begin{array}{c}\text { Plant height } \\
(\mathrm{Cm})\end{array}$ & $\begin{array}{c}\text { Number of Leaves } \\
(\text { Sheet) }\end{array}$ & $\begin{array}{c}\text { Total Chlorophyll } \\
\text { (SPAD) }\end{array}$ \\
\hline A (Chicken) & $32.06 \mathrm{ab}$ & $14.37 \mathrm{bc}$ & $57.39 \mathrm{~b}$ \\
\hline B (Pig) & $34.52 \mathrm{a}$ & $15.33 \mathrm{ab}$ & $57.21 \mathrm{~b}$ \\
\hline C (Goat) & $30.16 \mathrm{bc}$ & $13.04 \mathrm{~cd}$ & $56.04 \mathrm{bc}$ \\
\hline D (Cow) & $35.63 \mathrm{a}$ & $16.21 \mathrm{a}$ & $62.91 \mathrm{a}$ \\
\hline E (without Bioslurry) & $26.4 \mathrm{~d}$ & $12.08 \mathrm{~d}$ & $51.81 \mathrm{c}$ \\
\hline F (the habits Of farmers) & $27.17 \mathrm{~cd}$ & $11.75 \mathrm{~d}$ & $55.27 \mathrm{bc}$ \\
\hline
\end{tabular}

The same letter in the same column shows no significant difference in DMRT 5\%

Table.2 Effect of bio slurry application on generative growth and infection of clubroot on cabbage plants

\begin{tabular}{|l|c|c|c|c|c|}
\hline \multirow{2}{*}{$\begin{array}{l}\text { Bioslurry fertilizer from } \\
\text { livestock manure }\end{array}$} & \multicolumn{5}{|c|}{ Generative Growth of Cabbage Plants } \\
\cline { 2 - 6 } & $\begin{array}{c}\text { Number of } \\
\text { Club root } \\
\text { (pieces) }\end{array}$ & $\begin{array}{c}\text { Weight } \\
\text { Crop } \\
(\text { Gram) }\end{array}$ & $\begin{array}{c}\text { Plant } \\
\text { Weight } \\
(\text { Gram })\end{array}$ & $\begin{array}{c}\text { Root weight } \\
\text { (Gram) }\end{array}$ & $\begin{array}{c}\text { Percentage of } \\
\text { clubroot infection } \\
(\%)\end{array}$ \\
\hline A (Chicken) & $3.13 \mathrm{bc}$ & $810.83 \mathrm{ab}$ & $761.83 \mathrm{a}$ & $84.91 \mathrm{ab}$ & $66.67 \mathrm{c}$ \\
\hline B (Pig) & $3.70 \mathrm{~b}$ & $746.37 \mathrm{ab}$ & $856.79 \mathrm{a}$ & $110.42 \mathrm{a}$ & $45.83 \mathrm{c}$ \\
\hline C (Goat) & $3.87 \mathrm{~b}$ & $620.29 \mathrm{~b}$ & $696.54 \mathrm{a}$ & $85.91 \mathrm{ab}$ & $50.00 \mathrm{c}$ \\
\hline D (Cow) & $1.87 \mathrm{c}$ & $1040.12 \mathrm{a}$ & $759.96 \mathrm{a}$ & $83.08 \mathrm{ab}$ & $20.83 \mathrm{~d}$ \\
\hline E (without Bioslurry) & $7.87 \mathrm{a}$ & $150.70 \mathrm{c}$ & $53.71 \mathrm{c}$ & $53.70 \mathrm{~b}$ & $87.50 \mathrm{a}$ \\
\hline F (the habits of farmers) & $7.54 \mathrm{a}$ & $291.95 \mathrm{c}$ & $406.88 \mathrm{~b}$ & $86.25 \mathrm{ab}$ & $70.83 \mathrm{~b}$ \\
\hline
\end{tabular}

The same letter in the same column shows no significant difference in DMRT 5\% 


\section{Plants research in the field}
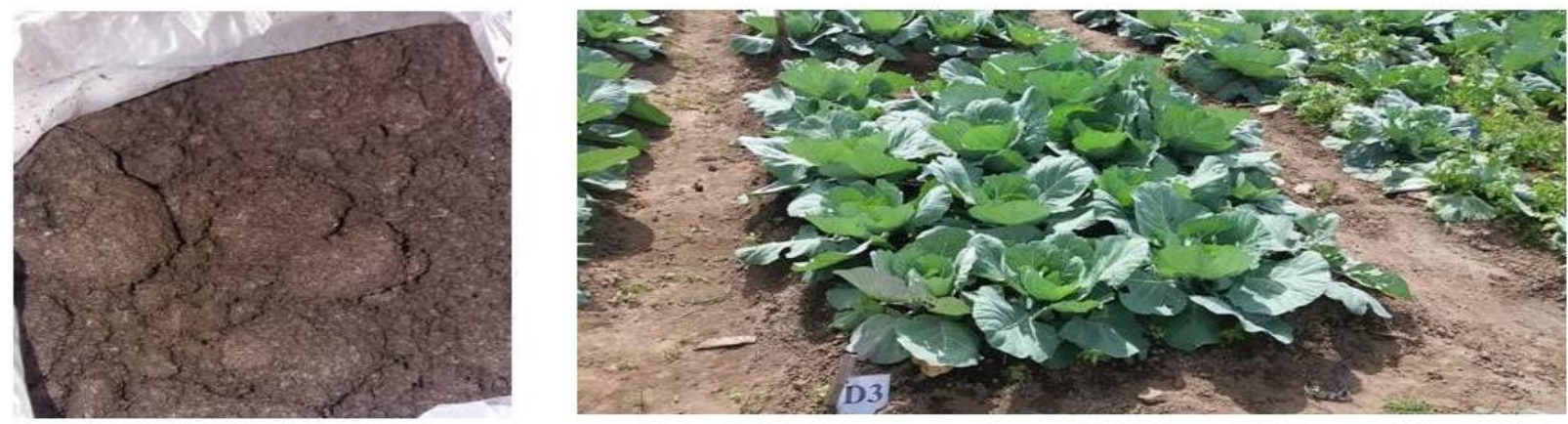

Figure.1 Bioslurry cow manure
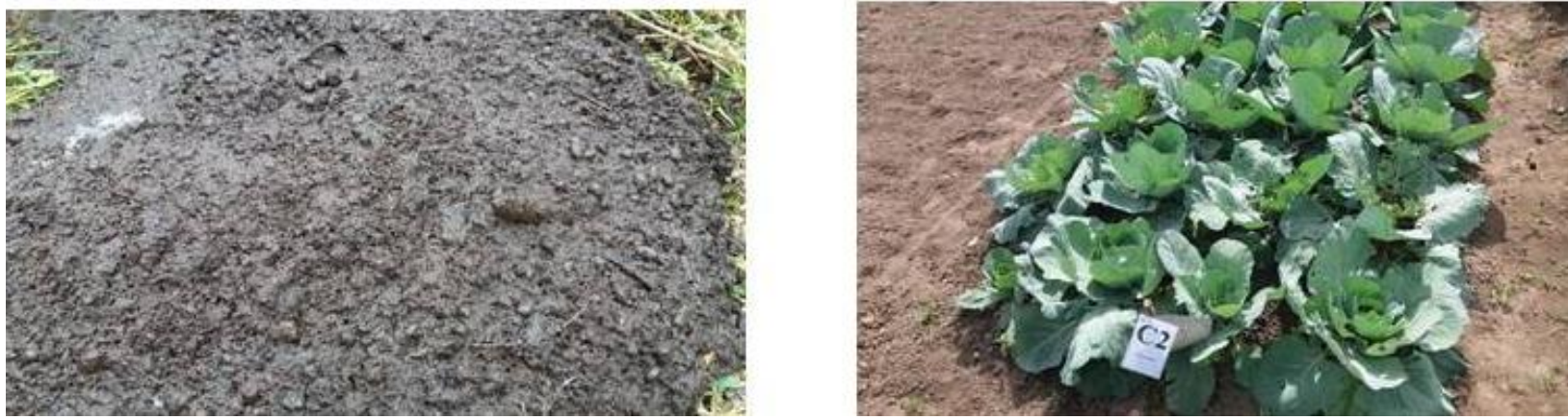

Figure.2 Bioslurry goat manure
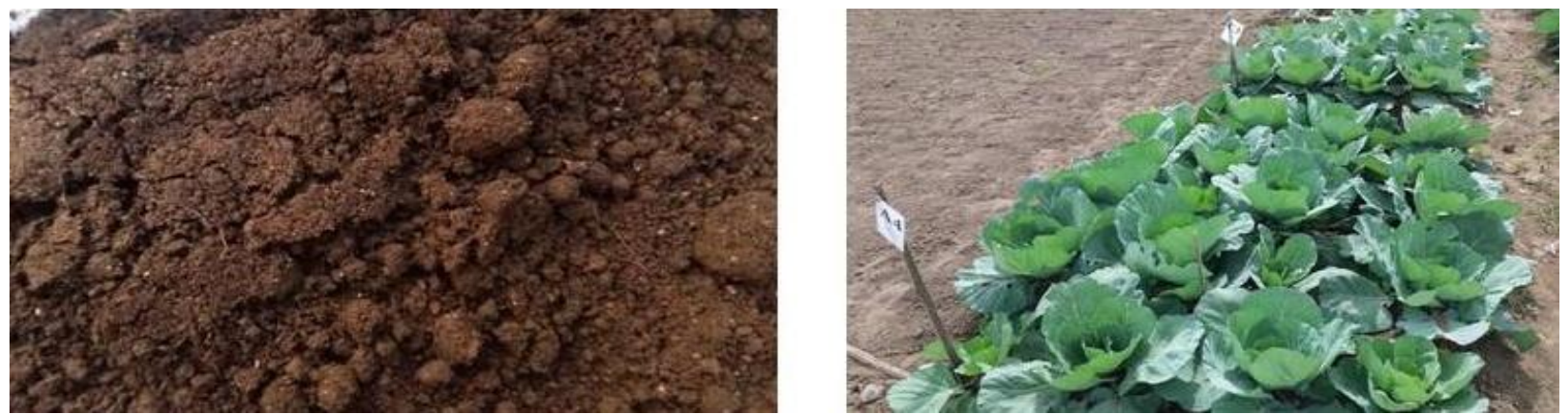

Figure.3 Bioslurry chicken manure
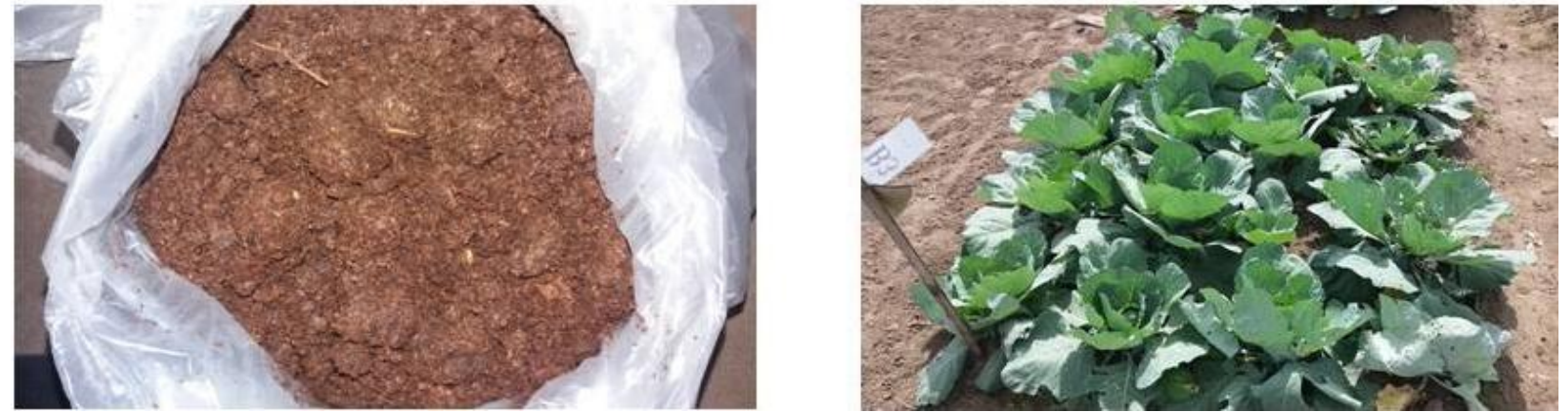

Figure.4 Bioslurry pig manure 


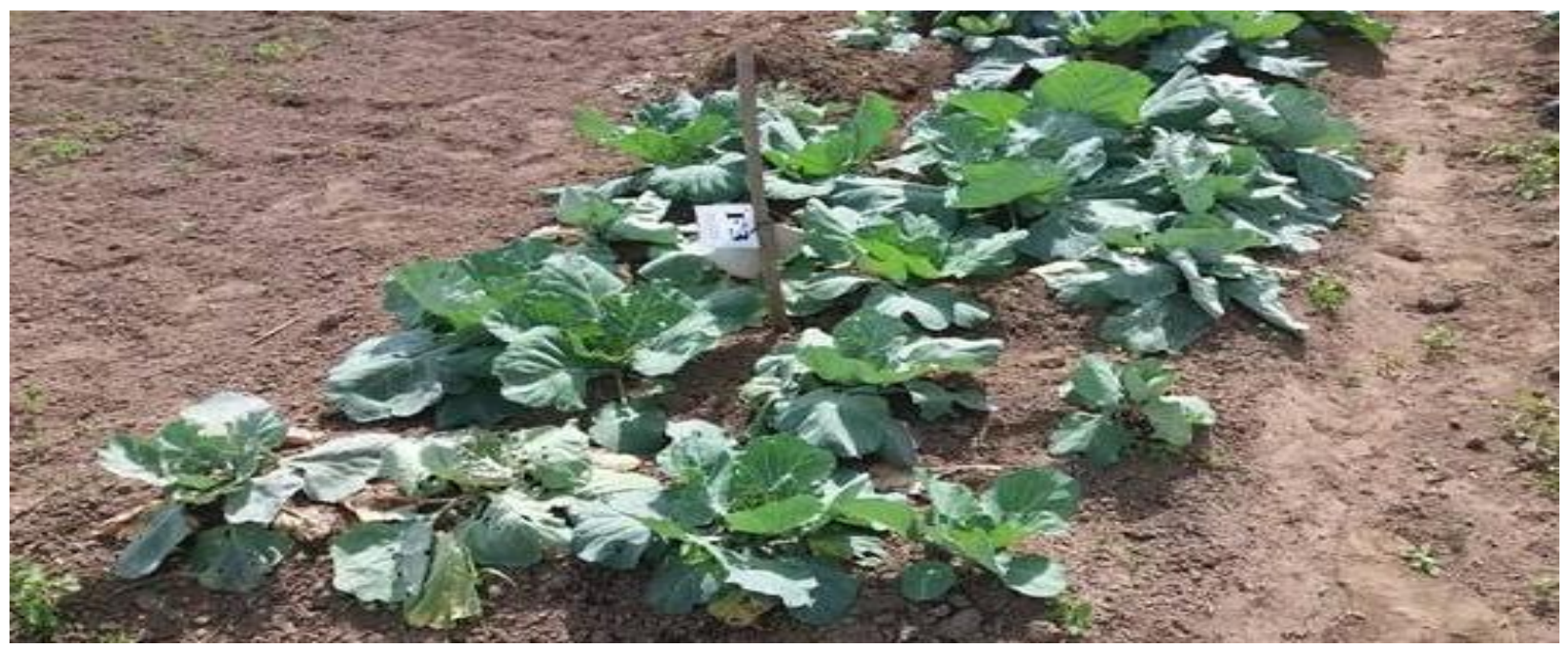

Figure.5 Control, without bioslurry and without fertilizer

\section{Conclusions and Suggestion}

The results of this study concluded that;

Organic fertilizer from waste of biogas reactor is quite good to be used to increase the growth of cabbage compared to organic fertilizer used by farmers. Namely bioslurry from Chicken manure (A), Pigs (B), Goat (C) and Cows (D),

Bioslurry from cow manure is very good to increase cabbage plant growth, both from plant height, number of leaves and number of leaf chlorophyll when compared to other bioslururry.

Bioslurry from goat manure is low in ability to increase the growth of cabbage.

In the case of protecting cabbage from infection by clubroot, use, Bioslurry organic fertilizers from cows can reduce the infection of clubroot, disease by $20.83 \%$, while control without using bioslurry the infection rate of club root disease reaches $70.33 \%$ to $87.50 \%$, while bioslurry from goat only able to reduce clubroot disease by only $50 \%$, so it is not good to be used as a controlling agent for clubroot.

\section{Suggestion}

To control clubroot in cabbage plants should use integrated control that is using organic fertilizer bioslurry from cow manure combined with Trichoderma biopesticides, using balanced fertilizing and good cropping

\section{Acknowledgement}

I would like to thank the Direktorat Riset dan Pengabdian kepada Masyarakat Direktorat Jendral Penguatan Riset dan Pengembangan Kementerian Riset Teknologi dan Pendidikan Tinggi for providing research funds so that research can work well.

\section{References}

Agrios, G.N. 1997. Plant Pathology. 4, ed. Academic Press, San Diego, California, London. 635 pp.

Agus S. 2013. Pengelolaan dan Pemanfaatan Biobio-slurry. https:// www. academia.edu/10389621/Pengelolaan_d an_Pemanfaatan_Biobio-slurry. Diakses tanggal 31 Desember 2015.

Arismansyah, E. A., 2010. Penyakit akar gada (Plasmodiophora brassicae Wor) 
pada kubis-kubisan dan upaya pengendaliannya. http://erlanardiana rismansyah.wordpress.com/2010/01/07/ penyakit-akar-gada-plasmodiophorabrassicae-wor-pada-kubis-kubisandan-upaya pengendaliannya.

Boteroa, C, B. D. Gossenc, S. E. Strelkova, C. D. Toddd, P. C. Smithd and E. L, Opez. 2019. Clubroot disease in Latin America: distribution and management strategies. Plant Pathology (2019) 68, $827-833$.

Cicu. 2006. Penyakit akar gada (Plasmodiophora brassicae Wor.) pada kubiskubisan dan upaya pengendalian. Balai Pengkajian Teknologi Pertanian. Sulawesi Selatan. 25(1):17.

Djatnika, I. 1984. Upaya penanggulangan $P$. brassicae Wor. pada tanaman kubiskubisan.hlm. Pp. 30-32. Prosiding Seminar Hama dan Penyakit Sayuran, Cipanas, Mei 1984. BPPT. Jakarta.

Hendriyani, N. M. Y., I K., Suada., and N W. Suniti. 2012. Pengendalian Penyakit Akar Gada yang Disebabkan oleh Plasmodiophora brassicae Wor.pada Tanaman Kubis (Brassica oleracea L. var. capitata L.) dengan Beberapa Ekstrak Tanaman. Agrotrop, 2(2): 197203.

Karling JS.1968. The Plasmodiophorales. 2nd ed. New York and London: Hafner Publishing Co. 256 p.

Klinton M, Agus Sutikno, dan Sri Yoseva, 2017. Pemberian pupuk organik bioslurry padat pada tanaman pakchoy (Brassica chinensis L.). JOM Faperta Vol. 4 No. 2 Oktober 2017; 1-11

Risnawaty, M. 2015. Respon Pertumbuhan dan Hasil Tanaman Caisim (Brassica
Rapa L.) Akibat Pemberian Pupuk Kotoran Sapi Olahan Biogas.

http://eprints.ung.ac.id/4437/1/2013-1-54211613409099-abstraksi 30072013070836 pdf. Diakses tanggal 1 November 2015.

Rukmana, R. 1994. Bertanam Petsai dan Sawi. Kanisius. Yogyakarta. 86pp.

Rusmiati, D., S. A. F., Kusuma, Y.,Susilawati, dan Sulistianingsih. 2007. Pemanfaatan Kubis (Brassica oleracea Var. Capitata Alba) Sebagai Kandidat Anti Keputihan. Jurnal. Bandung.

Sudrajat, Pita. 2014. Pengkajian pemanfaatan limbah biogas slurry dan sludge pada bibit tanaman kopi. https://www.academia.edu/7134552/Pen gkajian_pemanfaatan_limbah_biogas_B io-slurry dan Sludgepada_ bibit_tanaman_kopi. Di akses tanggal 22 Desember.

Sastrosiswojo, S, T. S. Uhan., and R. Sutarya. 2005. Penerapan Teknologi PHT pada Tanaman Kubis. Balai Penelitian Tanaman Sayuran; Monografi No. 21. Bandung.

Suryaningsih, E. 1981. Penyakit akar pekuk (Plasmodiophora brassicae Wor.), penyebaran dan cara pemberantasannya. Kongres Nasional Perhimpunan Fitopatologi Indonesia ke VI Padang.

Voorrips, R. 1995. Plasmodiophora brassicae: Aspects of pathogenesis and resistance in Brassica oleracea. Euphytica 83: 139-146.

Widodo and Suheri. 1995. Suppression of clubroot disease of cabbage by soil solarization. Buletin Hama Penyakit Tumbuhan 8(2):49-55.

\section{How to cite this article:}

Made Sudana, I., Gusti Ngurah Raka and Arta Jaya, D.P. 2019. Utilization of Biogas Reactor Waste (Bio-slurry) to Control of Club Root Disease on Cabbage Plants (Brassica oleracea L.). Int.J.Curr.Microbiol.App.Sci. 8(09): 415-421. doi: https://doi.org/10.20546/ijcmas.2019.809.050 